\title{
Hubungan Tingkat Pengetahuan dengan Perilaku Pencegahan Penularan Covid-19 pada Masyarakat
}

\section{Relationship between Knowledge Level and Behavior to Prevent Covid-19 Transmission in the Community}

\author{
Iin Patimah ${ }^{1}$, Sri Yekti W ${ }^{2}$, Rudy Alfiansyah ${ }^{3}$, Hasbi Taobah ${ }^{4}$, Devi Ratnasari $^{5}$, Andri Nugraha ${ }^{6}$ \\ ${ }^{1,4}$ Program Studi Sarjana Keperawatan, STIKes Karsa Husada Garut, Indonesia \\ ${ }^{2,3,5,6}$ Program Studi Profesi Ners, STIKes Karsa Husada Garut, Indonesia
}

\section{ARTICLE INFO \\ Article history \\ Received date \\ 03 Nov 2020 \\ Revised date \\ 06 Nov 2020 \\ 11 Mar 2021 \\ Accepted date \\ 06 Apr 2021}

\section{Keywords:}

Behavior;

Covid-19;

Knowledge;

Prevention.

\section{Kata kunci:}

Perilaku;

Covid-19;

Pengetahuan;

Pencegahan.

\author{
ABSTRACT/ ABSTRAK
}

The number of Covid-19 in various countries continues to increase every day, various efforts have been made by the government in various countries, one of which is in Indonesia, one of the efforts that have been made is education. Education is the first step to form behavior that can reduce the spread of Covid-19. The purpose of this research is to find out whether there is a relationship between knowledge about the prevention of transmission of Covid-19 with prevention behavior of transmission of Covid-19 in the community in the Garut district. This type of research is a cross-sectional study, using data collected online based on reports from 145 respondents. The research data were analyzed using the chi-square to assess the relationship between knowledge and behavior. The results showed that more than half of the respondents already had good knowledge, namely $77,2 \%$, and $67 \%$ of respondents have good behavior. From the results of statistical tests obtained p-value $0,06(>0,05)$, it can be concluded that there is no significant relationship between the level of knowledge about the prevention of Covid-19 and the behavior to prevent the spread of Covid-19. Given that there are several findings in research and limitations in the study, therefore, it is hoped that in the future various parties can examine other factors related to the level of knowledge about and behavior to prevent the spread of Covid-19 in various communities in various regions, districts, cities and countries.

\begin{abstract}
Angka kejadian Covid-19 di berbagai negara terus menerus mengalami peningkatan setiap harinya, berbagai usaha untuk mencegah penyebaran lebih lanjut telah dilakukan oleh pemerintah di berbagai negara salah satunya dengan memberikan edukasi, edukasi sebagai langkah awal untuk membentuk prilaku yang dapat mengurangi penyebaran Covid-19. Tujuan penelitian ini adalah untuk mengetahui apakah terdapat hubungan antara pengetahuan mengenai pencegahan penularan Covid-19 dengan perilaku pencegahan penularan Covid-19 pada masyarakat di Kabupaten Garut. Jenis penelitian ini adalah studi cross-sectional, menggunakan data yang dikumpulkan melalui online berdasarkan laporan dari 145 responden. Data hasil penelitian dianalisis dengan menggunakan chi squre untuk menilai adanya hubungan antara pengetahuan dan perilaku. Hasil penelitian menunjukan bahwa lebih dari sebagian responden sudah memiliki pengetahuan yang baik yaitu sebanyak $77,2 \%$ dan $67 \%$ responden mempunyai perilaku yang baik. Dari hasil uji statistik diperoleh p-value $0,06(>0,05)$, dapat disimpulkan tidak terdapat hubungan yang cukup signifikan antara tingkat pengetahuan tentang pencegahan Covid-19 dengan perilaku pencegahan penyebaran Covid-19. Mengingat terdapat beberapa temuan dalam penelitian serta keterbatasan dalam penelitian ini, maka diharapkan pada masa mendatang berbagai pihak dapat meneliti faktor lain yang berhubungan dengan tingkat pengetahuan tentang dan perilaku pencegahan penyebaran Covid-19 pada berbagai masyarakat di berbagai daerah, kabupaten, kota maupun negara.
\end{abstract}

Corresponding Author:

Iin Patimah

Program Studi Sarjana Keperawatan, STIKes Karsa Husada Garut, Indonesia

Email: iin.patimah84@gmail.com 
Pada awal tahun 2020, sebanyak 216 Negara digemparkan dengan penyakit yang dikenal dengan Coronavirus Disease 2019 (Covid-19). Covid-19 adalah penyakit infeksi yang disebabkan oleh severe acute respiratory syndrome coronavirus 2 (SARS-CoV-2) sebelumya dikenal dengan istilah Novel Corona Virus, yang pertama kali ditemukan di Wuhan Provinsi Hubei di China (Jayaweera, et al., 2020; Shereen, et al., 2020). Covid-19 menyebabkan gejala yang muncul dari gejala ringan sampai dengan berat bahkan menyebabkan komplikasi penyakit lain seperti ARDS (Acure Respiratory Death Syndrome), Akut cardiac injury, infeksi sekunder, infeksi paru-paru (pneumonia), Middle-East Respiratory Syndrome (MERS), dan Severe Acute Respiratory Syndrome (SARS) bahkan kematian gangguan pernafasan ringan sampai dengan berat (Santoso, et al., 2020; Team, n.d., 2020).

SARS-CoV-2 sampai saat ini telah banyak menginfeksi karena kemampuan penyebaran infeksi yang sangat cepat, dikarenakan afinitas virus ini sangat tinggi pada ACE2 (Lu \& Sun, 2020). SARS-CoV-2 dapat menyebar melalui kontak langsung ataupun tidak langsung. Penyebaran kontak langsung berasal dari orang pembawa virus berbicara, batuk,, bersin, droplet atau percikannya langsung mengenai orang lain (Chan, et al., 2020; Cook, 2020; Luo, et al., 2020; Liu J, et al., 2020; Liu Y, et al., 2020) sedangkan kontak tidak langsung dapat melalui benda yang terkontaminasi dan penularan melalui udara.

Angka kejadian Covid-19 di berbagai negara terus menerus mengalami peningkatan setiap harinya, Di Indonesia pada tanggal 13 September 2020 tercatat kasus terkonfirmasi sebanyak 218.382 kasus, dengan kematian 8.732 kasus angka tersebut masih meningkat setiap harinya seiring dengan tracing massif di berbagai daerah (Gugus Tugas Percepatan Penanganan Covid-19 RI, 2020). Belum tersedianya vaksin atau pengobatan yang efektif melawan komplikasi yang lebih berat lagi dari infeksi SARS-CoV-2 telah memaksa banyak negara memberlakukan tindakan lockdown yang ketat, termasuk penutupan sekolah untuk mengurangi penyebaran virus, dan membatasi kegiatan yang menimbulkan kerumunan banyak orang. Namun, ada kekhawatiran dari tindakan yang dilakukan seperti: penutupan sekolah memiliki konsekuensi yang merugikan pada kebutuhan pendidikan dan sosial serta mental dan kesejahteraan anak. Selain itu pembatasan sosial berdampak pada berhentinya roda ekonomi masyarakat yang dapat berimbas pada krisis ekonomi.
Pemerintah Indonesia merespon pandemi Covid-19 ini dengan berbagai langkah seperti: 1) larangan bepergian ke tempat umum (social distancing), 2) Anjuran menggunakan masker saat beraktivitas di tempat umum, 3) Rutin mencuci tangan dengan sabun atau hand sanitizer yang mengandung alkohol, 4) menutup mulut dan hidung menggunakan tisu saat batuk atau bersin, 5) tingkatkan daya tahan tubuh dan menghindari stres. Langkah awal yang dilakukan pemerintah yaitu melakukan sosialisasi kepada masyarakat. Langkah tersebut diharapkan menjadi langkah pencegahan penularan Covid-19 melalui edukasi massal menggunakan berbagai media. Kementerian Kesehatan Republik Indonesia melalui direktorat promosi kesehatan dan pemberdayaan masyarakat gencar mengeluarkan media sebagai bahan edukasi untuk masyarakat.

World Health Organization (WHO) telah menyatakan bahwa langkah penting dalam mengendalikan penyakit menular seperti Covid19 diantaranya melalui: edukasi, isolasi, tindakan preventif, pencegahan, pengendalian penularan, dan pengobatan orang yang terinfeksi (Lotfi, et al., 2020). Pemerintah Indonesia meningkatkan kewaspadaan terutama dalam hal mencegah penyebaran Covid-19 yaitu melalui penguatan dari masyarakat sendiri maupun penguatan dari pemerintah. Penguatan pencegahan penyebaran Covid-19 dari pemerintah, berupa dikeluarkannya berbagai kebijakan ketat untuk mengurangi pergerakan dan kontak sosial penduduknya. Strateginya termasuk penutupan perbatasan, pengurangan layanan yang tidak penting, dan larangan berkumpulnya massa untuk mengurangi jumlah orang ke orang. Selain penguatan yang datangnya dari pemerintah, sangat penting penguatan dari masyarakat sendiri berupa kepatuhan terhadap aturan pemerintah, seperti social distancing, cuci tangan, dan penggunaan masker wajah, diterapkan ke berbagai tingkatan di seluruh area yang terkena dampak. Strategi intervensi yang diprakarsai pemerintah hanya dapat berumur pendek, jika parah dan konsekuensi ekonomi dan sosial yang bertahan lama harus diminimalkan.

Berbagai usaha pemerintah Indonesia dilakukan untuk memberikan edukasi kepada masyarakat. Edukasi sebagai langkah awal untuk menyadarkan masyarakat bahwa Covid-19 dapat ditekan dengan mengubah perilaku. Edukasi yang sudah dilaksanakan dengan menggunakan dan mengoptimalisasikan pemanfaatan laman (website) seperti whatsapp, facebook, Instagram, dan media sosial lainnya. 
Harapan yang diinginkan dari edukasi adalah perubahan perilaku agar masyarakat menampakan perilaku untuk mencegah penyebaran Covid-19. Informasi yang didapatkan diharapkan dapat menjadi self imposed, melalui usaha pendekatan pencegahan penularan virus corona dimulai menjaga jarak sosial, mencuci tangan, dan penggunaan masker wajah, diterapkan di berbagai wilayah yang terkena dampak. Perubahan perilaku dalam diri sendiri bahwa pencegahan yang dilakukan sendiri, sebagai reaksi terhadap penyebaran informasi tentang penyakit COVID-19 dapat menjadi strategi efektif untuk memitigasi dan menunda epidemi (Teslya, et al., 2020).

Informasi yang disebarkan melalui metode edukasi bertujuan untuk meningkatkan pengetahuan seseorang, dalam hal ini bertujuan pada peningkatan pengetahuan masyarakat dalam pencegahan penularan Covid-19. Pengetahuan merupakan hasil dari informasi yang ditangkap melalui pendindraan terhadap suatu objek tertentu, ketika seseorang mendapatkan informasi, informasi tersebut dianalisa untuk selanjutnya diproses dan ditempatkan sesuai dengan tempatnya maka muncullah yang dinamakan pengetahuan (Islam \& Khan, 2014) (Irnawati, 2019). Pengetahuan terkait pencegahan penyebaran virus corona, merupakan sekumpulan informasi yang dirancang dengan tujuan untuk mengurangi angka kesakitan maupun kematian karena Covid-19.

Kenyataan yang ada di masyarakat berbagai macam media untuk mensosialisasikan pencegahan penularan Covid-19 sudah ditingkatkan, namun masih banyak perilaku masyarakat yang tidak sesuai seperti: mudik di hari raya atau cuti bersama, tempat wisata masih banyak dikunjungi oleh wisatawan baik dalam maupun luar kota, tempat umum seperti pasar masih menjadi tempat berkumpul pembeli dan pedagang, masih ditemukannya masyarakat tanpa menggunakan masker ketika hendak keluar rumah. Hal tersebut sampai saat ini masih banyak ditemukan di masyarakat sekitar padahal angka Covid-19 di Indonesia belum menunjukan adanya penurunan.

Tujuan penelitian ini adalah untuk mengetahui apakah terdapat hubungan antara pengetahuan mengenai pencegahan penularan Covid-19 dengan perilaku pencegahan penularan Covid-19 pada masyarakat di Kabupaten Garut.

\section{METODE}

Metode penelitian ini berupa penelitian kuantitatif dengan analitik observasional dan menggunakan rancangan cross-sectional. Variabel dependen dalam penelitian ini adalah pengetahuan masyarakat Garut terkait pencegahan penyebaran Covid-19 dan variabel independent adalah perilaku masyarakat garut terkait pencegahan penyebaran Covid-19. Populasi dalam penelitian ini adalah seluruh masyarakat garut. Penentuan teknik pengambilan sampel menggunakan cluster random sampling. Dari 11.729.134 jumlah populasi masyarakat garut dengan usia >14 tahun, terdapat 195 yang mengembalikan kuesioner berbasis online. Setelah menyesuaikan kelengkapan data dan karakteristik jumlah sampel dalam penelitian ini adalah 145 responden yang bersedia menjadi sampel dalam penelitian ini. Kriteria responden yang dijadikan subjek dalam penelitian ini adalah masyarakat Garut yang berusia >14 tahun, mampu membaca, tidak ada gangguan psikikologis dan kognitif, bersedia menjadi responden. Semua peserta menyetujui protokol penelitian dan memberikan persetujuan tertulis.

Penelitian ini berfokus untuk mengetahui hubungan antara pengetahuan dan perilaku, instrumen dikembangkan oleh peneliti dengan menggunakan materi promosi kesehatan dari kementerian kesehatan mengenai Panduan Pencegahan Penularan Covid-19 untuk Masyarakat. sebelum instrumen ini dibagikan, terlebih dahulu dilakukan uji validitas dan reliabilitas pada masyarakat Garut yang tidak masuk dalam subjek penelitian ini. Pengambilan data pada penelitian ini menggunakan kuesioner melalui media online yaitu google form yang dibagi menjadi 4 bagian yakni bagian pertama adalah data demografi meliputi usia, jenjang pendidikan, pekerjaan, dan jenis kelamin, bagian kedua kuesioner terdiri dari pengetahuan pencegahan penularan Covid-19 sebanyak 4 pertanyaan, dan bagian ketiga perilaku pencegahan penularan Covid-19 sebanyak 6 pertanyaan. Analisis bivariat dilakukan menggunakan chi-square untuk menentukan hubungan antara variabel pengetahuan dengan perilaku. Pengujian dilakukan dengan menggunakan significance level 0,05.

Penelitian ini telah melewati telaah etik dan mendapatkan Keterangan Layak Etik (Ethical Excemption) dengan Nomor 19/KEPK/SDHB/B/XII/2020 dari Komite Etik Penelitian Kesehatan Sekolah Tinggi Ilmu Kesehatan Dharma Husada Bandung. 


\section{HASIL}

\begin{tabular}{lrr} 
Tabel 1. Distribusi & \multicolumn{2}{c}{$\begin{array}{c}\text { Frekuensi } \\
\text { berdasarkan Karakteristik }\end{array}$} \\
\hline \multicolumn{1}{c}{ Karakteristik } & Responden \\
\hline Usia & $\%$ \\
$18-29$ & 55 & 38 \\
$30-39$ & 41 & 28 \\
$40-49$ & 33 & 23 \\
$50-59$ & 10 & 7 \\
$>60$ & 6 & 4 \\
Jenjang Pendidikan & & \\
SMA ke bawah & 41 & 28 \\
D3/S1 & 88 & 61 \\
S2/S3 & 16 & 11 \\
Pekerjaan & & \\
ASN / PNS & 29 & 20 \\
Karyawan & 15 & 10 \\
Lain-lain & 59 & 41 \\
Pelajar & 35 & 24 \\
Wiraswasta & 7 & 5 \\
Jenis Kelamin & & \\
Laki-Laki & 55 & 38 \\
Perempuan & 90 & 62 \\
\hline
\end{tabular}

Pada tabel 1 diketahui bahwa sebagian besar responden berada dalam rentang dewasa; $38 \%$ (55) berusia 18-29, dan sebagian kecil yaitu $4 \%$ (6) berada dalam rentang usia >60 tahun. Dilihat dari jenjang pendidikan lebih dari setengahnya $61 \%$ (88) jenjang pendidikan tinggi yaitu S1/D3 dan sebagian kecil berada dalam jenjang pendidikan S2/S3 11\% (16) sedangkan sisanya sebanyak $28 \%$ (41) jenjang pendidikan SMA ke bawah. Selanjutnya dilihat dari pekerjaan, sebagian besar (41\%) responden memiliki pekerjaan lainnya. Dilihat dari jenis kelamin, lebih dari setengahnya $62 \%$ berjenis kelamin perempuan.

Tabel 2. Hubungan Tingkat Pengetahuan dengan Perilaku Pencegahan Covid 19

\begin{tabular}{|c|c|c|c|c|c|c|}
\hline \multirow{3}{*}{ Pengetahuan } & \multicolumn{4}{|c|}{ Perilaku } & \multirow{2}{*}{\multicolumn{2}{|c|}{ Total }} \\
\hline & \multicolumn{2}{|c|}{ Kurang } & \multicolumn{2}{|c|}{ Baik } & & \\
\hline & $\mathbf{n}$ & $\%$ & $\mathbf{n}$ & $\%$ & $\mathrm{n}$ & $\%$ \\
\hline Baik & 76 & 52 & 37 & 26 & 113 & 77 \\
\hline Kurang & 13 & 9 & 19 & 13 & 32 & 22 \\
\hline Total & 89 & 61 & 56 & 39 & 145 & 100 \\
\hline$p$-value & 0,06 & & & & & \\
\hline
\end{tabular}

Berdasarkan tabel 2, sebanyak 76 responden $(52 \%)$ memiliki pengetahuan yang baik serta sebagian besar (61\%) perilaku yang kurang terhadap pencegahan penularan Covid19. Reponden yang memiliki pengetahuan baik sebagian besar meanmpilkan perilaku kurang terhadap pencegahan penularan Covid-19. Dari hasil uji statistik di peroleh $p$-value $0,06(>0,05)$ yang berarti hipotesis nol diterima, artinya tidak terdapat hubungan yang cukup signifikan antara tingkat pengetahuan dengan perilaku pencegahan Covid-19.

\section{PEMBAHASAN}

Pengetahuan merupakan hasil dari informasi yang ditangkap melalui pendindraan terhadap suatu objek tertentu, ketika seseorang mendapatkan informasi, informasi tersebut dianalisa untuk selanjutnya diproses dan ditempatkan sesuai dengan tempatnya maka muncullah yang dinamakan pengetahuan (Islam \& Khan, 2014) (Irnawati, 2019). Pengetahuan terkait pencegahan penyebaran virus corona, merupakan sekumpulan informasi yang dirancang dengan tujuan untuk mengurangi angka kesakitan maupun kematian karena Covid-19.

Pada hasil peneltian ini diketahui sebagian besar (77\%) responden memiliki pengetahuan yang sudah baik. Pengetahuan seseorang terkait informasi tertentu dipengaruhi oleh beberapa faktor, diantaranya: jenis pekerjaan, pendidikan, umur, pengalaman, kebudayaan dan informasi (Sundari, 2018).

Pengetahuan adalah hasil dari tahu dan terjadi setelah seseorang kontak terhadap suatu objek melalui panca indera, berupa pendengaran, penciuman, penglihatan, perasaan serta perabaan. Indra yang sering digunakan untuk menghasilkan pengetahuan yaitu penglihatan berupa mata dan indera pendengaran, tidak hanya itu informasi yang diterima melalui pancaindra tentang topik tertentu dipahami serta dipertahankan untuk selanjutnya digunakan menurut kebutuhan.

Pengetahuan yang dimiliki seseorang sebagian besar berasal dari proses pendidikan baik itu Pendidikan yang sifatnya formal maupun informal. Selain dari proses Pendidikan pengetahuan juga bisa seseorang dapatkan berumber dari pengalaman baik itu pengalaman pribadi maupun pengalaman orang lain yang dipelajari. Selain itu pengetahuan bisa bersumber dari media massa serta hasil interaksi dengan lingkungan (Siltrakool, 2018).

Dari hasil penelitian sebagian besar responden mempunyai pengetahuan dalam kategori baik. Hal ini sapat didukung dan dipengaruhi oleh tingkat pendidikan responden. Berdasarkan hasil penelitian pada responden, responden hampir seluruhnya berada pada tingkat Pendidikan tinggi yaitu tingkat D3 dan S1 ke atas sisanya 28\% (41) berada pada jenjang Pendidikan SMA ke bawah. Faktor pendidikan menjadi salah satu penentu pengetahuan, hasil riset ini 
menujukan pengetahuan dari responden tergolong baik.

Kenyataan ini didukung oleh beberapa hasil penelitian yang meneliti hubungan pengetahuan dengan tingkat pendidikan pada populasi berbeda di Indonesia mengenai: kesehatan reproduksi pada ibu rumah tangga Tangga di Desa Rukoh Kecamatan Syiah Kuala Banda Aceh (Asiah., 2009); Papsmear pada ibu rumah tangga di Desa Kauman Sragen (Wicaksono, 2013); Menopause pada ibu rumah tangga di desa Kresen Bantul (Megawati, 2012); swamedikasi demam pada anak menggunakan obat parasetamol pada orang tua di kalangan masyarakat Kecamatan Talango, Kabupaten Sumenep, Jawa Timur (Marjan, 2018); Kesehatan gigi dan mulit pada guru penjaskes SD di kecamatan Tampak Siring Gianyar (Dharmawati \& Wirata, 2016).

Dari penelitian tersebut diketahui makin tinggi pendidikan seseorang main tinggi pula pengetahuannya. Semakin tinggi tingkat pendidikan seseorang maka semakin tinggi juga seseorang menerima informasi terhadap sesuatu hal, sehingga akhirnya semakin banyak juga pengetahuan yang dimilikinya. Sebaliknya jika seseorang dengan tingkat pendidikan yang rendah, maka hal tersebut menghambat sikap seseorang untuk menerima informasi dan nilainilai yang baru diperkenalkan.

Pada hasil penelitian ini diketahui juga seluruh responden berusia $>19$ tahun. Faktor usia juga sangat memengaruhi pengetahuan seseorang. Semakin bertambahnya usia seseorang maka semakin berkembang juga daya tangkap seseorang sehingga meningkatkan pengetahuan seseorang ditambah faktor pengalaman (Budiman \& Riyanto, 2013). Berdasarkan penelitian yang dilakukan dapat disimpulkan sebanyak 145 responden, hampir setengah dari responden memiliki perilaku positif mengenai Covid-19 yaitu berhati-hati dan memiliki tindakan usaha peningkatan kesehatan pribadi. Pemberian pengetahuan yang spesifik, valid, dan tepat sasaran diharapkan dapat meningkatkan perilaku usaha pencegahan masyarakat terhadap infeksi Covid-19. Namun berdasarkan hasil analisis bivariat pada penelitian ini tidak ditemukan adanya hubungan antara pengetahuan dan perilaku pencegahan penyebaran Covid-19. Berdasarkan teori kognitif soaial, menyebutkan bahwa perilaku seseorang tidak hanya dipengaruhi oleh faktor internal seperti motivasi, tujuan, dan kemauan, namun juga dipengaruhi oleh faktor eksternal yaitu lingkungan. Selain itu, ada faktor lainnya yang memengaruhi perilaku diantaranya: pembelajaran, efikasi diri, kontrol diri, kemampuan emosional, pembelajaran melalui observasi, dan motivasi/ penguatan.

Selain hal tersebut, perilaku seseorang juga dipengaruhi oleh tiga faktor yaitu: 1) faktor predisposisi, 2) faktor pendorong, dan 3) faktor penguat. Pengetahuan, kepercayaan, sikap, keyakinan, sosio demografi serta nilai-nilai yang dianut seseorang merupakan faktor predisposisi untuk terbentuknya perilaku. Faktor predisposisi adalah faktor yang memengaruhi seseorang berperilaku. Faktor lainnya ada juga faktor pendorong, yaitu faktor yang memungkinkan seseorang berperilaku. Yang termasuk faktor pendorong adalah lingkungan, sarana kesehatan, fasilitas Kesehatan dan sumber sumber khusus yang mendukung. Faktor lainnya yang memperngaruhi perilaku adalah faktor penguat. Faktor penguat adalah faktor yang bisa memperkuat terbetuknya perilaku. Faktor penguat diantaranya adalah tokoh masyarakat, kelompok tertentu.

Hasil penelitian ini betentangan dengan hasil penelitian yang serupa yang menghubungkan pengetahuan dan sikap pada populasi berbeda mengenai penanganan combustion pada pedagang gorengan (Robby, 2019); memeriksakan diri ke pelayanan kesehatan pada pasien glukoma (Fauzian, et al., 2016). Namun hasil penelitian ini sejalan dengan hasil penelitian yang dilakukan oleh beberapa peneliti yang sama melakukan penelitian hubungan pengetahun dan sikap pada populasi yang berbeda mengenai pencegahan HIV/AIDS pada remaja komunitas anak jalanan di kabupaten kudus (Irsyad, et al., 2014); cuci tangan pakai sabun (CTPS) pada masyarakat di desa Senuro Timur (Fajar \& Misnaniarti, 2011); Periksa Payudara Sendiri (SADARI) pada mahasiswa Fakultas Ilmu Keperawatan universitas Padjadjaran (Seftiani, 2014).

Perilaku adalah respon yang dapat diamati baik disadari maupun tidak dari seseorang terdhadap adanya stimulus baik dari dalam maupun dari luar individu (Wawan \& Dewi, 2010). Menurut Sunaryo (2004) faktor yang memengaruhi perilaku manusia yaitu faktor internal dan eksternal; 1) Faktor internal seperti ras, jenis kelamin, sifat/karakteristik fisik, kepribadian dan Intelegensi; 2) Faktor eksternal seperti faktor lingkungan (fisik, biologis maupun sosial), pendidikan, agama, kepercayaan, sosial budaya dan faktor ekonomi. Perilaku yang nampak pada seseorang pada dasarnya ibentuk melalui tiga cara: 1) Pembiasaan, 2) Pembentukan prilaku dengan knowledge, 3) Pembentukan perilaku dengan menggunakan model. Salah satu cara pembentukan perilaku 
dapat ditempuh dengan conditioning atau pembiasaan. Dengan cara membiasakan diri untuk berperilaku seperti yang diharapkan, akhirnya akan terbentuklah perilaku tersebut.

Pembiasaan merupakan salah satu cara dalam memberikan pendidikan pada seseorang, Seseorang yang telah mempunyai kebiasaan untuk melakukan sesuatu maka seseorang akan lebih mudah dan dengan senang hati untuk dapat melaksanakannya. Bahkan, segala sesuatu yang sudah menjadi kebiasaan dalam usia dini aka akan lebih sulit dirubah sampai dengan usia lanjut. Tujuan pembiasaan adalah untuk membentuk kebiasaan, memperbaiki kebiasaan atau mempelajari kebiasaan. Pembiasaan ini bisa dengan berbagai cara seperti: menggunakan model sebagai role model untuk pembentukan perilaku, menggunakan reward and punishment dengan tujuan agar seseorang memperoleh perilaku yang beru yang lebih positif dan tepat (Hajar, 2013).

Disamping pembentukan perilaku dengan conditioning atau kebiasaan, pembentukan perilaku dapat ditempuh dengan knowledge. Pembentukan melakui knowledge didasarkan pada teori belajar kognitif, yaitu belajar dengan disertai adanya pengertian. Peran kognitif dalam pembentukan perilaku diantaranya: memberikan pengertian, menghadilkan emosi, memntuk sikap, memberikan motivasi terhadap konsekuensi perilaku.

Selain cara-cara pembentukan perilaku seperti tersebut di atas, pembentukan perilaku masih dapat ditempuh dengan menggunakan model atau contoh. Model atau contoh yang bisa digunakan dalam membentuk perilaku seperti pemimpin, tokoh agama, atau panutan. Cara ini didasarkan atas Social learning theory atau teori belajar sosial yang dikemukakan oleh Bandura. Social learning theory adalah teori yang menjelaskan pengaruh sosial terhadap perkembangan kepribadian. Teori ini mengkaji bagimana individu yang sedang berosialisasi memengaruhi seseorang dalam aspek: proses pembelajaran, pembentukan kepribadian seseorang dan lingkungan. Memandang pembentukan kepribadian seseorang merupakan outcome dari respon atas stimulus sosial. Perilaku dan sikap seseorang tumbuh karena dorongan atau peneguhan dari orang-orang di sekitarnya (Juachon, n.d.). Terdapat tiga konsep inti dalam social learning theory: 1) seseorang belajar melalui pengamatan atau observasi, 2) mental atau batin seseorang merupakan bagian penting dalam proses ini, 3) pembelajran belum tentu menghasilkan perubahan perilaku (Cherry, 2011).
Pembelajaran yang menghadirkan pengetahuan yang baik belum tentu menghasilkan perubahan perilaku hal ini terjadi pada penelitian ini. Pengetahuan masyarakat Garut yang baik yang berasal dari pembelajaran dari berbagai media mengenai cara pencegahan penularan Covid-19 belum tentu menghasilkan perilaku untuk mencegah penularan Covid-19. Proses pembentukan perilaku melalui social learning theory pada dasarnya akan melewati beberapa tahapan yaitu: tahap memperhatian, tahap mengingat, tahap menunjukan kemampuannya dan terakhir motivasi. Motivasi penting karena hal tersebut menjadi penggerak bagi seseorang untuk terus melakukan sesuatu. sehingga, seseorang harus termotivasi untuk meniru perilaku yang telah dipelajari dari pemodelan (Cherry, 2011).

Saat ini berbagai media digunakan sebagai media edukasi untuk membentuk perilaku masyarakat melalui pengetahuan. Media merupakan salah satu sumber pendukung dalam transfer knowledge atau juga sebaliknya dapat menjadi penghambat dalam terwujudnya komunikasi yang efektif (Patimah, et al., 2018). selain itu pembentukan perilaku juga dipengaruhi oleh adanya stimulasi dari luar yaitu dengan adanya reinforcement dan punishment. reinforcement adalah proses di mana akibat atau perubahan yang terjadi dalam lingkungan memperkuat perilaku tertentu di masa datang . Skinner menyarankan, penyebab eksternal juga bisa menjelaskan alasan suatu perilaku. Skinner menyebut ada tiga jenis stimulus yang terjadi setelah suatu perilaku. Ada stimulus netral, reinforcement alias penguat, dan punishment alias hukuman (McLeod Saul, 2018). Perilaku yang diikuti dengan adanya reinforcement cenderung akan di ulangi sedangkan sebaliknya hukuman merujuk pada setiap peristiwa yang melemahkan atau mengurangi kemungkinan suatu perilaku dilakukan.

Dari apa yang ada dalam penelitian secara umum pengetahuan masyarakat Garut sudah bisa dikatakan baik mengenai pencegahan penyebaran Covid-19, namun berdasarkan uji analisa data statistik pada penelitian ini, tidak ada hubungan yang signifikan. Untuk pembentukan perilaku dipengaruhi berbagai faktor dan juga dibutuhkan penguatan agar mampu membiasakan perilaku, penguatan tersebut bisa dengan dorongan luar baik dari pemerintah berupa reinforcement dalam bentuk hukuman yang tegas untuk masyarakat yang melanggar aturan protocol pencegahan Covid-19 dan juga stimulus dari luar yaitu dari petugas. Petugas kesehatan sebagai bagian integral dalam pelayanan kesehatan 
mampu menjadi motivasi eksternal. Sehingga pengetahuan tidak hanya diadopsi saja namun juga tampak dengan perilaku yang baik (Nugraha, et al., 2019).

\section{SIMPULAN}

Berdasarkan hasil penelitian dapat disimpulkan bahwa tidak ada hubungan antara pengetahuan dengan perilaku pencegahan penyebaran Covid-19. Kemungkinan ada beberapa faktor lain yang sangat kuat untuk membentuk perilaku seseorang salah satunya penguatan baik dari dalam diri maupun luar. Berdasarkan hasil penelitian ini masih diperlukan lagi kajian lain untuk menilai faktor lain yang memengaruhi dalam perilaku seseorang terutama mengenai perilaku pencegahan penyebaran Covid-19.

\section{DAFTAR PUSTAKA}

Asiah, M. D. (2009). Hubungan tingkat pendidikan dengan pengetahuan kesehatan reproduksi ibu rumah tangga di Desa Rukoh Kecamatan Syiah Kuala Banda Aceh. Jurnal Biologi Edukasi, 1(2), 1-4.

Budiman dan Riyanto A. (2013). Kapita Selekta Kuisioner Pengetahuan dan Sikap dalam Penelitian Kesehatan. Jakarta: Salemba Medika.

Chan, J. F. W., Yuan, S., Kok, K. H., To, K. K. W., Chu, H., Yang, J., Xing, F., Liu, J., Yip, C. C. Y., Poon, R. W. S., Tsoi, H. W., Lo, S. K. F., Chan, K. H., Poon, V. K. M., Chan, W. M., Ip, J. D., Cai, J. P., Cheng, V. C. C., Chen, H., .. Yuen, K. Y. (2020). A familial cluster of pneumonia associated with the 2019 novel coronavirus indicating person-to-person transmission: a study of a family cluster. The Lancet, 395(10223), 514-523. https://doi.org/10.1016/S01406736(20)30154-9

Cherry, K. (2011). Social learning theory: An overview of Bandura's social learning theory. The New York Times Company.

Cook, T. (2020). Personal protective equipment during the COVID-19 pandemic - a narrative review. Anaesthesia, 75 . https://doi.org/10.1111/anae.15071

Dharmawati, I. G. A. A., \& Wirata, I. N. (2016). Hubungan Tingkat Pendidikan, Umur, Dan Masa Kerja Dengan Tingkat Pengetahuan Kesehatan Gigi Dan Mulut Pada Guru Penjaskes Sd Di Kecamatan Tampak Siring Gianyar. Jurnal Kesehatan Gigi Vol., 4(1), 1-5. http://www.poltekkesdenpasar.ac.id/keperawatangigi/wpcontent/uploads/2017/02/ilovepdf_merged.pd $\mathrm{f}$

Fajar, N. A., \& Misnaniarti. (2011). Hubungan Pengetahuan Dan Sikap Terhadap Perilaku Cuci Tangan Pakai Sabun Pada Masyarakat Di Desa Senuro Timur. Jurnal Pembangunan Manusia, 5(1), 1-7.

Fauzian, R., Rahmi, F., \& Nugroho, T. (2016). Hubungan Tingkat Pengetahuan Dengan Perilaku Memeriksakan Diri Ke Pelayanan Kesehatan: Penelitian Pada Pasien Glaukoma Di Rumah Sakit Dr. Kariadi. Jurnal Kedokteran Diponegoro, 5(4), 1634-1641.

Gugus Tugas Percepatan Penanganan COVID-19 RI. (2020). Gugus Tugas Percepatan Penanganan COVID-19. In Beranda covid19.go.id (pp. 1-1). https://covid19.go.id/

Hajar, H. (2013). Pembentukan Prilaku anak melalui metode pembiasaan bercerita di RA Ulil Albab Sungguminasa Kabupaten Gowa.[Skripsi]. Makassar: Universitas Islam Negeri (UIN) Alaudin Makasar.

Irnawati, Suriah, Y. (2019). View of Pengaruh Edukasi Melalui Media Whats App dan Leaflet Terhadap Perubahan Perilaku Berisiko Pada Siswa. Window of Health : Jurnal Kesehatan, 2. http://jurnal.fkmumi.ac.id/index.php/woh/a rticle/view/167/81

Irsyad, C., Setiyadi, N. A., \& Wijayanti, A. C. (2014). Hubungan Antara Pengetahuan dan Sikap Dengan Perilaku Pencegahan HIV/AIDS Pada Remaja Komunitas Anak Jalanan di Kabupaten Kudus. Prosiding Seminar Nasional Fakultas Ilmu Kesehatan, 205(01), 71-77. http://eprints.ums.ac.id/30523/1/ARTIKEL _PUBLIKASI.pdf

Islam, M. S., \& Khan, R. H. (2014). Exploring the factors affecting knowledge sharing practices in Dhaka University Library. Library Philosophy and Practice, 2014(1).

Jayaweera, M., Perera, H., Gunawardana, B., \& Manatunge, J. (2020). Transmission of COVID-19 virus by droplets and aerosols: A critical review on the unresolved dichotomy. Environmental Research, 188, 109819. https://doi.org/10.1016/j.envres.2020.109819 
Juachon, L. (n.d.). Theories of Learning: Social Cognitive Theory. EDS 103 - Theories of Learning Kitomarketing.Com, 1-10.

Luo, L., Liu, D., Liao, X. L., Wu, X. B., Jing, Q. L., Zheng, J. Z., ... \& Mao, C. (2020). Modes of contact and risk of transmission in covid-19: a prospective cohort study 4950 close contact persons in guangzhou of China. https://papers.ssrn.com/sol3/papers.cfm?abst ract_id=3566149

Liu, J., Liao, X., Qian, S., Yuan, J., Wang, F., Liu, Y., Wang, Z., Wang, F.-S., Liu, L., \& Zhang, Z. (2020). Community Transmission of Severe Acute Respiratory Syndrome Coronavirus 2, Shenzhen, China, 2020. Emerging Infectious Diseases, 26(6), 13201323.

https://doi.org/10.3201/eid2606.200239

Liu, Y., Ning, Z., Chen, Y., Guo, M., Liu, Y., Gali, N. K., Sun, L., Duan, Y., Cai, J., Westerdahl, D., Liu, X., Ho, K., Kan, H., $\mathrm{Fu}$, Q., \& Lan, K. (2020). Aerodynamic Characteristics and RNA Concentration of SARS-CoV-2 Aerosol in Wuhan Hospitals during COVID-19 Outbreak. 86(21). https://doi.org/10.1101/2020.03.08.982637

Lotfi, M., Hamblin, M. R., \& Rezaei, N. (2020). COVID-19: Transmission, prevention, and potential therapeutic opportunities. Clinica chimica acta.

Lu, J., \& Sun, P. D. (2020). High affinity binding of SARS-CoV-2 spike protein enhances ACE2 carboxypeptidase activity. BioRxiv: The Preprint Server for Biology, 2020.07.01.182659.

https://doi.org/10.1101/2020.07.01.182659

Marjan, L. (2018). Hubungan Tingkat Pendidikan

Terhadap Tingkat Pengetahuan Orangtua dalam Swamedikasi demam pada anak menggunakan obat parasetamol. Studi Di Kalangan Masyarakat Kecamatan Talango, Kabupaten Sumenep, Jawa Timur. [islam negeri maulana Malik Ibrahum]. In New England Journal of Medicine (Vol. 372, Issue http://www.ncbi.nlm.nih.gov/pubmed/

McLeod Saul. (2018). B.F. Skinner| Operant Conditioning | Simply Psychology. Simply Psychology, 1948, 1-12. https://s3.amazonaws.com/academia.edu.

Megawati. (2012). Hubungan Tingkat pendidikan dengan tingkat pengetahuan ibu tentang menopause di dusun kresen bantul tahun 2012 (Vol. 66, Issue 3).

Megawati, M., \& Yunita, W. (2012). Hubungan Tingkat Pendidikan dengan Tingkat Pengetahuan Ibu tentang Menopause di
Dusun Kresen Bantul Tahun 2012. [Skripsi]. Yogyakarta: STIKES 'Aisyiyah Yogyakarta.

Nugraha, L., Patimah, I., \& Suharta, D. (2019). Motivation to Implement Diet in Hypertension Patients. Jurnal Aisyah: Jurnal Ilmu Kesehatan, 4(1), 83-90. https://doi.org/10.30604/jika.v4i1.182

Patimah, I., Megawati, S. W., \& Suryawantie, T. (2018). Efektivitas Metode Pembelajaran Cooperative Learning Terhadap Kemampuan Komunikasi pada Mahasiswa. Jurnal Pendidikan Keperawatan Indonesia, 4(1), https://doi.org/10.17509/jpki.v4i1.12347

Robby, A. (2019). Jurnal Kesehatan Komunitas Indonesia. Vol 15 No 1, Maret 2019. Sikap Keluarga Dalam Perawatan Pasien Stroke Di Ruang L RSU X Tasikmalaya, 15(1), 111.

Santoso, A., Pranata, R., Wibowo, A., Al-Farabi, M. J., Huang, I., \& Antariksa, B. (2020). Cardiac injury is associated with mortality and critically ill pneumonia in COVID-19: A meta-analysis. American Journal of Emergency Medicine, xxxx. https://doi.org/10.1016/j.ajem.2020.04.052

Seftiani, d. (2012). Hubungan tingkat pengetahuan dengan perilaku sadari pada mahasiswa fakultas ilmu keperawatan universitas padjadjaran. Students e-Journal, 1(1), 31. http://jurnal.unpad.ac.id/ejournal/article/view 1729 .

Siltrakool, B. (2018). Assessment of community pharmacists' knowledge, attitude and practice regarding non-prescription antimicrobial use and resistance in Thailand. [Thesis]. University of Hertfordshire.

Shereen, M. A., Khan, S., Kazmi, A., Bashir, N., \& Siddique, R. (2020). COVID-19 infection: Origin, transmission, and characteristics of human coronaviruses. Journal of Advanced Research, 24, 91-98. https://doi.org/10.1016/j.jare.2020.03.005

Sundari1, A. M. (2018). View of Increases Knowladge Exclusive Breastfeeding at Mother in Makassar. Windows Of Health. http://jurnal.fkmumi.ac.id/index.php/woh/a rticle/view/woh1104/4

Sunaryo. (2004). Psikologi untuk keperawatan. Editor: Monica Ester. Jakarta : EGC.

Team, T. N. C. P. E. R. E. (n.d.). The Epidemiological Characteristics of an Outbreak of 2019 Novel Coronavirus Diseases (COVID-19) - China, 2020. China CDC Weekly, 2(8), 113-122. 
https://doi.org/10.46234/ccdcw2020.032

Teslya, A., Pham, T. M., Godijk, N. G., Kretzschmar, M. E., Bootsma, M. C. J., \& Rozhnova, G. (2020). Impact of selfimposed prevention measures and shortterm government-imposed social distancing on mitigating and delaying a COVID-19 epidemic: A modelling study. PLOS Medicine, 17(7), e1003166. https://doi.org/10.1371/journal.pmed.1003 166
Wawan, A \& Dewi, M. (2010). Teori dan Pengukuran Pengetahuan, Sikap dan Perilaku Manusia. Yogyakarta: Nuha Medika.

Wicaksono, P. P. (2013). Hubungan Tingkat Pendidikan dengan pengetahuan ibu rumah tangga tentang Pap Smear di Desa Kauman Kecamatan Tangen Kabupaten Sragen, Muhamadiyah Surakarta. [Skripsi]. Surakarta: Fakultas Kedokteran, Universitas Muhammadiyah Surakarta. 